\title{
TAMAN AIR RAMAH ANAK DI KOTA PELAIHARI
}

\author{
Nurgisdarani Basri \\ Program Studi Teknik Arsitektur Fakultas Teknik Universitas Lambung Mangkurat \\ h1b115024@mhs.ulm.ac.id
}

\author{
Akbar Rahman \\ Program Studi Teknik Arsitektur Fakultas Teknik Universitas Lambung Mangkurat \\ arzhi_teks@ulm.ac.id
}

\begin{abstract}
ABSTRAK
Taman Air Ramah Anak di Kota Pelaihari dirancang dengan Standar Ruang Bermain Ramah Anak agar anak dapat bermain dengan aman dan nyaman, serta belajar mengenal air sejak dini. Metode yang digunakan pada perancangan ini adalah "Arsitektur Perilaku" dengan perilaku anak sebagai pertimbangan utama desain. Pendekatan desain menggunakan "Pendekatan Psikologi" dengan psikologi anak sebagai pendekatan utama dalam desain ini. Mempertibangkan pengunjung yang datang sangat beragam maka konsep program yang digunakan adalah "Flexibility". Elemen dan ruang taman dibuat dengan beragam fungsi dan bentuk mengikuti konsep program yang telah ditentukan. Diharapkan dengan adanya taman ini anak-anak dapat bermain dengan aman dan nyaman serta dapat belajar mengenal air sejak dini dengan menyenangkan.
\end{abstract}

Kata kunci: Taman Air, Ruang Bermain, Ramah Anak, Arsitektur Perilaku, Psikologi Anak

\section{ABSTRACT}

The Child Friendly Water Park in Pelaihari City is designed with Child Friendly Playroom Standards so that children can play safely and comfortably, and learn to recognize water from an early age. The method used in this design is "Behavioral Architecture" with children's behavior as the main design consideration. The design approach uses a "Psychological Approach" with child psychology as the main approach in this design. Considering the number of visitors who come, the concept of the program used is "Flexibility". Garden elements and spaces are made with various functions and forms following a predetermined program concept. It is hoped that with this park children can play safely and comfortably and can learn to recognize water from an early age with fun.

Keyword : Water Park, Playroom, Kid Friendly, Behavioral Architecture, Child Psychology

\section{PENDAHULUAN}

Masyarakat lebih banyak mengetahui keuntungan ruang terbuka hijau secara sosial. Ruang terbuka hijau juga memiliki peran penting secara fisik berhubungan dengan iklim mikro kawasan yang berguna secara ekologis. Adanya vegetasi dan penghijauan pada ruang terbuka hijau akan memperbaiki iklim mikro sehingga dapat membuat udara bergerak menjadi lebih baik, 
menahan angina kencang akibat perubahan cuaca secara signifikan, terjadinya perubahan suhu udara menjadi lebih sejuk, pengurangan polutan udara, dan pengurangan karbon dioksida sehingga oksigen akan banyak dihasilkan.

Vegetasi yang banyak dapat mengurangi suhu panas luar ruangan. Taman yang berdekatan dengan area perairan terasa lebih sejuk di siang hari dan terasa lebih hangat di malam hari (Rahman, 2017). Air yang memanas karena sinar matahari akan memiliki tekanan udara yang rendah. Pohon-pohon yang berperan sebagai vegetasi akan memiliki tekanan udara yang tinggi. Udara yang memiliki tekanan lebih tinggi akan mengarah ke tempat dimana ada udara bertekanan rendah. Sehingga sirkulasi angin pada taman akan berhembus ke berbagai arah sehingga akan menyejukkan taman dan menimbulkan rasa nyaman bagi pengunjung taman.

Gerakan Revolusi Hijau ditetapkan pada tanggal 30 April 2018 di dalam Peraturan Daerah Provinsi Kalimantan Selatan Nomor 7 Tahun 2018. Pemerintah Kota Pelaihari memiliki program Kabupaten Ramah Anak sebagai salah satu upaya peningkatan nilai kota. Untuk mewujudkan program pemerintah tersebut maka taman-taman di kota Pelaihari akan diperbaiki agar dapat memenuhi Standar Ruang Bermain Ramah Anak. Salah satu taman yang akan diperbaiki secara keseluruhan adalah Taman Kijang Kencana.

\section{PERMASALAHAN}

Pemerintah Kota Pelaihari ingin memperbaiki Taman Kijang Kencana agar dapat menjadi ruang terbuka hijau yang memenuhi standar Ruang Bermain Ramah Anak. Pada Taman tersebut dibuat berbagai macam media air sebagai penghias taman yang nantinya akan menjadi salah satu ciri khas Kota Pelaihari. Taman tersebut juga mempunyai edukasi untuk anak-anak dan area rekreasi yang rindang. Dapat disimpulkan bahwa rumusan permasalahan pada perancangan taman ini adalah
"Bagaimana rancangan Taman Air Anak-Anak yang dapat memberikan keamanan dan kenyamanan bagi pengunjung sesuai Standar Ruang Bermain Ramah Anak?"

\section{TINJAUAN PUSTAKA}

\section{A. Taman}

Arifin et al (2008) berpendapat bahwa taman kota adalah taman umum dalam skala kota yang peruntukannya sebagai fasilitas untuk rekreasi, olahraga, dan sosialisasi masyarakat kota yang bersangkutan.

Taman edukasi yang dilengkapi dengan fasilitas dan juga sarana yang tepat pada taman tersebut dapat menunjang tingkat edukasi pada taman tersebut bagi penggunanya. Berikut merupakan elemen pendukung taman sesuai dengan persyaratan Ruang Bermain Ramah Anak, yaitu :

a. Ada rambu dan marka yang jelas dan mudah terbaca serta mudah terlihat.

b. Terdapat papan khusus untuk pengumuman-pengumuman di samping papan informasi dan papan sertifikasi RBA. Papan pengumuman dapat diisi/ditempel informasi/ pengetahuan yang berkaitan dengan anak, permainan, kesehatan, dll.

c. Penggunaan vegetasi/ tumbuhan/ tanaman endemik lokal pada lokasi indoor dan/atau outdoor sebagai usaha dari Pengembangan ilmu pengetahuan dan Konservasi.

d. Vegetasi/ tumbuhan/tanaman diberi keterangan.

e. Unsur vegetasi/ tumbuhan/ tanaman bisa digunakan juga sebagai perangkat bermain.

f. Ada papan yang berisi peraturan yang jelas tentang tata-tertib bermain untuk indoor dan outdoor.

g. Harus ada panduan/ user manual yang dipasang pada papan keterangan tentang tata cara penggunaan dan manfaat perabot bermain anak. 
h. Tersedianya ruang yang juga bisa digunakan untuk bermain yang bersifat seni.

i. Ada CCTV, peluit/kentongan/sirine keamanan dan papan informasi tentang sistem keamanan RBA dan perabotannya.

j. Terdapat tempat sampah yang terorganisir seperti terdapat pemisah antara organik, non organik.

k. Terdapat papan penanda larangan merokok di sekitar area bermain.

Taman air dapat diwujudkan dengan adanya kolam, air mancur, air terjun buatan, dan berbagai hal yang menggunakan media air sebagai unsur utama pembentuk estetika. Kedalaman air yang tidak terlalu dalam pada taman sangat diperhitungkan apalagi jika taman tersebut ditujukan untuk anak-anak.

\section{B. Ruang Bermain Ramah Anak}

Terdapat beberapa persyaratan dalam perencanaan Ruang Bermain Ramah Anak yang dibahas dalam Undang-Undang Nomor 20 Tahun 2014 yang membahas mengenai Standardisasi dan Penilaian Kesesuaian, yaitu : Lokasi, Material, Kemudahan, Penghawaan Udara, Keselamatan, Kesehatan atau Kebersihan, Pencahayaan, Pemanfaatan, Vegetasi, Peralatan Bermain, Keamanan, Kenyamanan, dan Pengelolaan.

Ada pula beberapa ketentuan dalam pengembangan Ruang Bermain Ramah Anak, yaitu kepentingan terbaik untuk anak, aman dan selamat, partisipasi anak, kreatif dan inovatif, non diskriminatif, nyaman, sehat. dan gratis

Tahap pertumbuhan anak yang berkaitan dengan kemampuan anak dalam meningkatkan kecerdasan dan kepandaian anak. Kegiatan di luar ruangan sangat penting untuk perkembangan kognitif, fisik, sosial dan psikologis (emosional anak), serta perkembangan spiritual. (Mustapa dkk, 2015, dalam Aji 2016). Oleh karena itu ruang bermain yang terencana akan mendukung perkembangan anak.
Pengalaman dalam berinteraksi sosial dapat mengembangkan kemampuan berpikir anak dalam kegiatan kelompok dengan teman sebayanya. Anak-anak belajar cara-cara mendekati orang yang jarang atau bahkan belum pernah ditemuinya. Sikap yang akan ditunjukkan anak yaitu sikap malu-malu atau berani, sikap menjauhkan diri atau bersahabat. Anak-anak cenderung membawa kebiasaan-kebiasaan sosial tersebut dalam seluruh kehidupan sehari-harinya.

\section{Psikologi Anak}

Terdapat beberapa perkembangan psikologi anak antara lain sebagai berikut:

1. Tahapan Trust and Mistrust

Anak akan belajar mengenai sifat kepercayaan dan ketidakpercayaan yang sangat berpengaruh terhadap perkembangan anak.

2. Tahap Autonomy and Shame and Doubt

Anak akan mulai diajari untuk mandiri secara perlahan serta mengatasi rasa malu ataupun ragu.

3. Tahapan Initiative and Guilt

Anak diharapkan sudah bisa melakukan beberapa aktivitasnya secara mandiri. Anak akan diajarkan dan diberitahu jika melakukan kesalahan serta belajar untuk mengatasi perasaan bersalah yang ia rasakan.

\section{Arsitektur Perilaku}

Perilaku manusia bisa menjadi pertimbangan terbentuknya arsitektur tapi bentuk arsitektur yang telah dirancang juga dapat membentuk perilaku manusia. Dunia anak sebagian besar digunakan untuk bermain dan menjadi kebutuhan dasar anak. Manfaat bermain bagi anak adalah mengembangkan kreativitas, karakter, sensorik dan motorik, kognitif, moral dan etika, kesadaran diri, bahasa dan juga sebagai terapi. Maka seharusnya anak lebih banyak bermain dan bersosialisasi agar anak terus berkembang. Permainan yang dimaksud adalah permainan outdoor maupun indoor secara individu atau 
berkelompok. Permainan yang dilakukan juga harus mengandung pembelajaran untuk anak. Perilaku sosial anak saat bermain dengan anak-anak lain akan membuat orang tua mengetahui karakter anak.

\section{PEMBAHASAN}

\section{A. Lokasi}

Taman berada di Kecamatan Pelaihari yang memiliki batas-batas wilayah yaitu : Kecamatan Tambang Ulang (Sebelah Utara), Kecamatan Panyipatan (Sebelah Selatan), Kecamatan Bajuin (Sebelah Timur), dan Kecamatan Takisung (Sebelah Barat)

a. Lokasi Tapak : Taman Kijang Kencana

b. Alamat Tapak : Jalan Pancasila, Kelurahan Karang Taruna, Kecamatan Pelaihari, Kabupaten Tanah Laut

c. Luas Tapak : $5940 \mathrm{~m} 2$

d. Jenis Tanah Tapak : Tanah Keras

e. Kontur Tanah : Berkontur

f. Fungsi Tapak : Taman Kota

g. GSB Utara Tapak : 5 meter

h. GSB Selatan, Timur, Barat Tapak : 3 meter

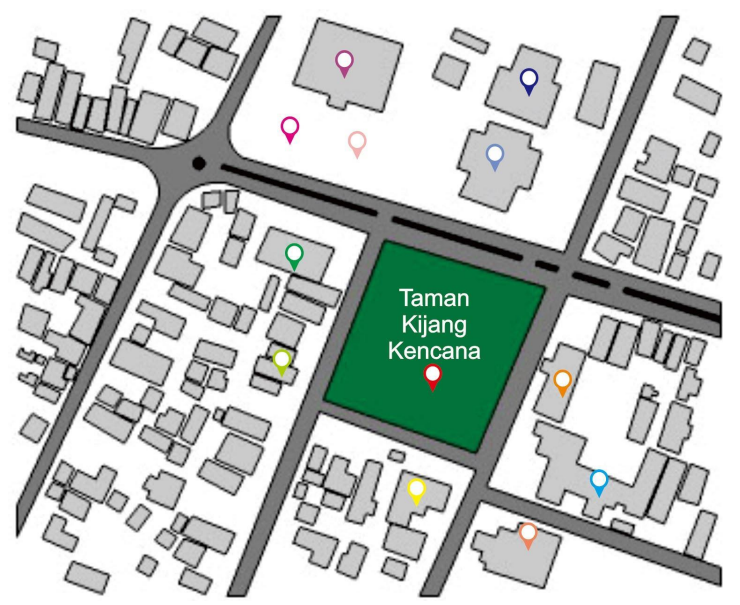

\section{Keterangan :}

Kediaman Bupati Tanah Laut

Kediaman Wakil Bupati Tanah Laut

Balairung Tuntung Pandang

Dinas Pemberdayaan Masyarakat dan Desa

TK AI-Qur'an Plus Waladun Sholeh

Penitipan Anak

BRI Cabang Pelaihari

Mini Cell

Gor Berseri Pelaihari

Lapangan Basket

Lapangan Voli

Gambar 1. Situasi Taman Kijang Kencana Sumber: Analisis Pribadi (2020)

\section{B. Konsep Rancangan}

1. Pelaku

Pelaku yang akan beraktivitas pada tapak terdiri dari 3 golongan yaitu Pengunjung, Penjual, dan Pengelola.

1. Pengunjung
a. Anak-Anak
b. Dewasa
c. Orang Tua

2. Penjual

3. Pengelola

\section{Aktivitas}

Terdapat berbagai aktivitas yang akan terjadi pada tapak, yaitu :

1. Kegiatan bermain

2. Kegiatan mengerjakan tugas

3. Kegiatan melihat-lihat pemandangan

4. Kegiatan bersantai

5. Kegiatan menemani anak-anak bermain

6. Kegiatan berjalan-jalan santai

7. Kegiatan makan dan minum

8. Kegiatan pengawasan area taman

9. Kegiatan pelayanan informasi

10. Kegiatan pelayanan penitipan barang

11. Kegiatan pelayanan parkir

12. Kegiatan pengelolaan taman

3. Luas Ruang

Tabel 1. Luasan Ruang Keseluruhan

\begin{tabular}{|l|c|}
\hline \multicolumn{1}{|c|}{$\begin{array}{c}\text { Nama } \\
\text { Bangunan/Ruang }\end{array}$} & \multicolumn{1}{c|}{$\begin{array}{c}\text { Jumlah } \\
\text { Luasan }\end{array}$} \\
\hline $\begin{array}{l}\text { Area Bermain dan } \\
\text { Permainan Air }\end{array}$ & $934.13 \mathrm{~m}^{2}$ \\
\hline
\end{tabular}




\begin{tabular}{|c|c|}
\hline Area Penjualan & $128.74 \mathrm{~m}^{2}$ \\
\hline Area Makan & $288.3 \mathrm{~m}^{2}$ \\
\hline Bangunan Pengelola & $62.5 \mathrm{~m}^{2}$ \\
\hline Bangunan Servis & $100 \mathrm{~m}^{2}$ \\
\hline Selasar Penghubung & $276.51 \mathrm{~m}^{2}$ \\
\hline Area Bermain Outdoor & $173.58 \mathrm{~m}^{2}$ \\
\hline Area Bermain Indoor & $100.3 \mathrm{~m}^{2}$ \\
\hline Jumlah Luasan & $2064.06 \mathrm{~m}^{2}$ \\
\hline
\end{tabular}

Sumber: Analisis Pribadi (2020)

4. Ruang Bermain Anak

Ruang bermain anak terbagi menjadi beberapa bagian yang memiliki kriteria tertentu yaitu ketinggian, lantai, ruang, dan alat bermain. Berikut kriteria masing-masing bagian area bermain anak yaitu :

1) Ketinggian

a. Apabila menggunakan tangga, tinggi antar tangga maksimal "10 cm"

b. Apabila terdapat perbedaan tinggi, area bermain harus dilengkapi dengan ramp.

c. Tangga dan ramp dilengkapi dengan pegangan tangga dengan berbagai ketinggian.

2) Lantai

a. Lantai ruang bermain tidak boleh licin dan tidak boleh keras.

b. lantai ruang bermain dilapisi dengan karpet busa bergambar agar aman apabila anak terjatuh dan menarik perhatian anak agar aktif bermain.

3) Ruang

a. Ruang bermain indoor tetap menggunakan penghawaan alami, pencahayaan alami saat siang hari dan pencahayaan buatan saat malam hari.

b. Ruang bermain indoor dibatasi oleh pagar pengaman yang transparan dan aman apabila anak berlarian dan menabrak pagar pengaman tersebut.

c. Ruang bermain indoor diberi kesan terbuka agar tidak mengganggu pandangan dan mempermudah orang tua dalam mengawasi anaknya.

d. Kolom pada area bermain harus berbentuk bulat dan diberi busa pengaman agar menjaga keamanan anak.

e. Perabot-perabot tambahan pada area bermain anak harus terbuat dari bahan yang tidak terlalu keras, tumpul atau diberikan diberikan penambahan busa pengaman.

4) Alat bermain

a. Alat bermain pada area bermain anak terbuat dari bahan yang memiliki lisensi SNI, tidak berbahaya apabila anak terbentur saat terjatuh atau diberikan tambahan busa pengaman.

b. Setiap alat bermain di area bermain anak diberikan keterangan umur dan berat anak yang dibolehkan untuk menggunakan alat bermain tersebut.

\section{HASIL}

Konsep program flexibility dipilih dengan berbagai pertimbangan, yaitu :

1. Pengunjung taman yang sangat beragam

2. Area taman yang harus bisa diakses oleh semua jenis pengunjung

3. Para pengunjung akan datang pada waktu yang beragam

4. Para pengunjung mengunjungi taman dengan tujuan yang beragam

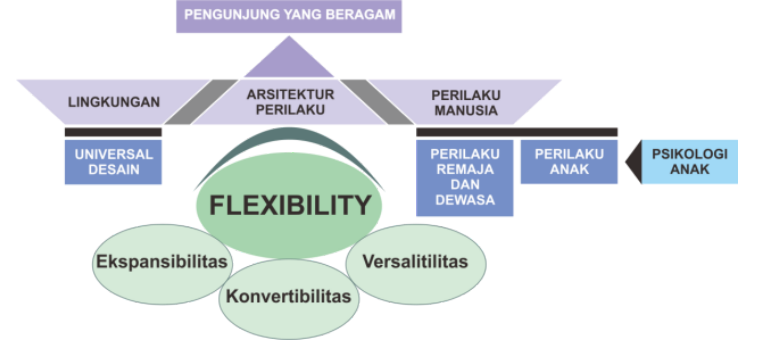


Gambar 2. Konsep Program Flexibility

Sumber: Analisis Pribadi (2020)

A. Konsep Ekspansibilitas

Zona taman terbagi menjadi dua yaitu zona taman terencana dan zona nyaman tak terencana yang menjadi area terbuka untuk publik. Pada zona tak terencana anak-anak akan diperbolehkan menggunakannya untuk bermain dengan kreativitasnya masing-masing. Pada zona ini akan terbentuk sendiri area bermain menyesuaikan kreativitas dari anak-anak yang bermain pada taman ini.

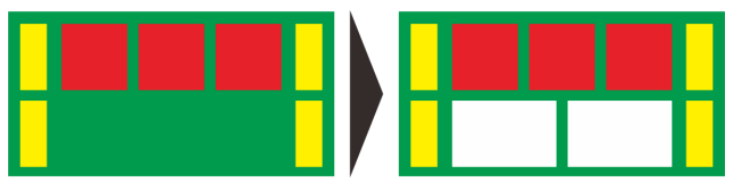

Gambar 3. Zona Terencana dan Tak Terencana Sumber: Analisis Pribadi (2020)

B. Konsep Konvertibilitas

Elemen tempat duduk yang tidak memiliki sandaran akan memudahkan bagi pengunjung untuk memilih view taman yang diinginkan. Elemen taman rerumputan yang bisa digunakan pengunjung untuk jalan pintas akan memiliki fungsi berbeda saat diberikan karpet sebagai pembatas ruang.

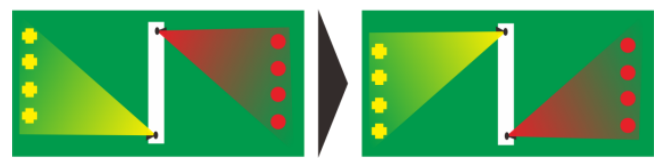

Gambar 4. Perbedaan Arah Duduk yang Menentukan View Taman yang Dilihat Sumber: Analisis Pribadi (2020)

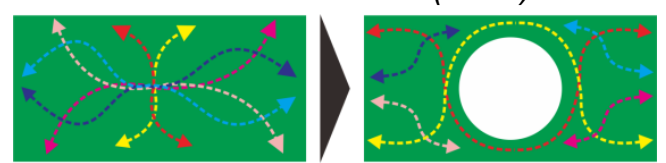

Gambar 5. Perubahan Arah Sirkulasi

Dikarenakan Terbentuknya Ruang Baru

Sumber: Analisis Pribadi (2020)

C. Konsep Versalitilitas

Perbedaan penggunaan ruang di waktu yang berbeda. Saat pagi hari area terbuka taman digunakan untuk olahraga sedangkan saat sore hari area terbuka taman digunakan untuk bersantai.

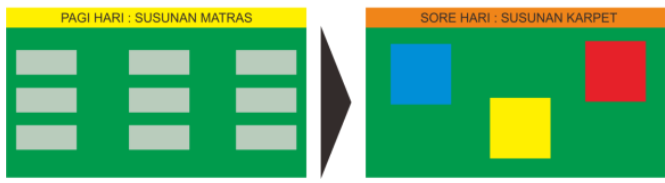

Gambar 6. Perbedaan Fungsi Ruang Dengan

Perbedaan Perabot

Sumber: Analisis Pribadi (2020)

Terdapat berbagai ruang yang

terbentuk pada taman, yaitu :

1. Bangunan Pengelola (ruang

keamanan, ruang panel, ruang informasi, dan ruang penyimpanan barang)

2. Bangunan Servis (ruang toilet perempuan, ruang toilet laki-laki, ruang toilet keluarga, ruang toilet difabel, lavatory, ruang tunggu)

3. Selasar Penghubung Bangunan Pengelola dan Bangunan Servis (area makan, area bermain indoor)

4. Area Penjualan (outlet penjualan, area makan)

5. Area bermain outdoor (ruang bermain permainan tradisional, ruang bermain permainan modern)

6. Area Bermain dan Permainan Air (permainan air, jalur skuter, area bermain air

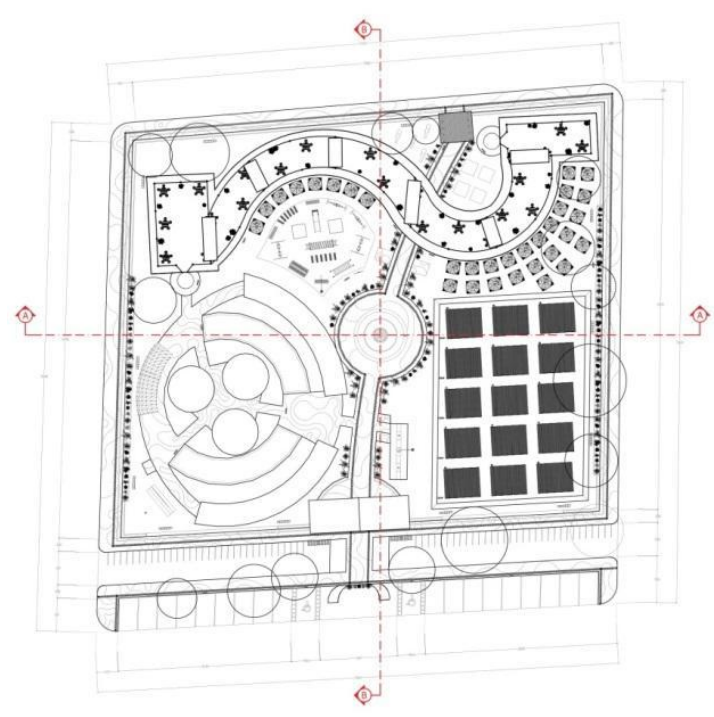

Gambar 7. Site Plan

Sumber: Analisis Pribadi (2020) 


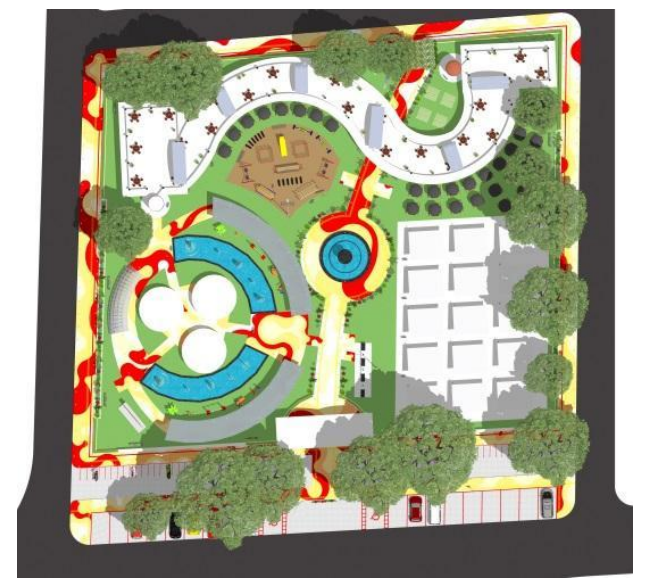

Gambar 8. Tampak Atas

Sumber: Analisis Pribadi (2020)

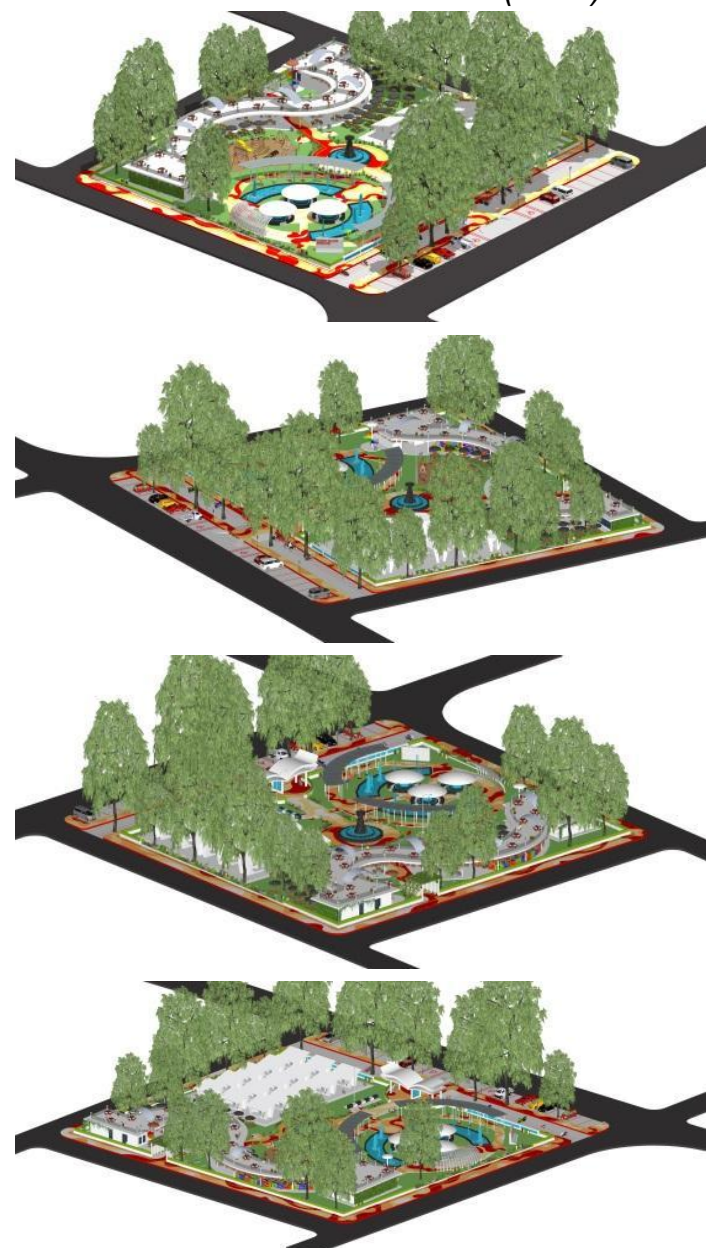

Gambar 9. Perspektif Eksterior Sumber: Analisis Pribadi (2020)

\section{KESIMPULAN}

Konsep program yang dipilih untuk menyelesaikan permasalahan desain adalah konsep Flexibility. Taman harus bisa diakses dengan aman dan nyaman oleh anak-anak namun kenyaman orang tua dalam mendampingi juga harus diperhatikan. Oleh karena itu, elemen-elemen taman selain menarik untuk anak-anak juga harus menarik bagi pendamping anak, yaitu remaja dan dewasa.

Air dipilih sebagai media utama taman, yang juga menjadi media edukasi yang akan ditampilkan pada taman ini. Iklim mikro kawasan juga menjadi pertimbangan melihat kondisi kawasan yang memiliki intensitas cahaya matahari yang tinggi serta curah hujan yang tak menentu. Pada hasil perancangan ini diharapkan agar anak-anak akan lebih senang dalam bermain dan bersosialisasi, serta para pengunjung lainnya akan mendapatkan relaksasi atau dapat melepas penat setelah berkunjung ke taman ini.

\section{DAFTAR PUSTAKA}

\section{Referensi Buku dan Jurnal}

Almuhaimin, EA. Budianto, C. Santoso, H. Fleksibilitas Artspace Dengan Lahan Minim (Studi Kasus Semeru Art Gallery). Malang : Universitas Brawijaya. [Internet]. [dinduh 2 Juli 2020]. Tersedia di:

https://pdfs.semanticscholar.org/dbc4/
50d403c44a8a4e1cf47c79483ff5357f4
0c4.pdf

Kurniati, Rizki. Broto, D. Pujo. 2019. Pengembangan Model Gerak Dasar Renang Berbasis Permainan Untuk Anak Usia 5-6 Tahun. Motion. 10(1): 10-21. [Internet]. [dinduh 1 Juli 2020]. Tersedia di:

http://jurnal.unismabekasi.ac.id/index.p $\mathrm{hp} / \mathrm{motion} /$ article/download/1625/1501

Rahman, A. Kojima, S. 2017. Study of Indoor and Outdoor Thermal Comfort for Public Space and Houses in Around River Case Study : 
Banjarmasin City, Indonesia. Advances in Engineering: an International Journal. 2(1): 29-41. [Internet]. Tersedia di: https://www.researchgate.net/publicati on/327164039

Universitas Atma Jaya Yogyakarta. Kajian Umum Tinjauan Taman Edukasi. [Internet]. [dinduh 23 Agustus 2020]. Tersedia di: http://e-journal.uajy.ac.id/11352/3/TA14 1592.pdf

Universitas Islam Negeri Maulana Malik Ibrahim. Kajian Teori. [Internet]. [dinduh 2 Juli 2020]. Tersedia di: http://etheses.uin-malang.ac.id/2115/6/ 08410137_Bab_2.pdf

\section{Website}

Badan Pemeriksa Keuangan Republik Indonesia. 2017. Peraturan Daerah Provinsi Kalimantan Selatan Nomor 7 Tahun 2018 tentang Gerakan Revolusi Hijau. [Internet]. Tersedia di:

https://peraturan.bpk.go.id/Home/Detai Is/103167/perda-prov-kalimantan-selat an-no-7-tahun-2018 diaskes pada 12 September 2019.

Genpi. 2019. Bangun Ruang Bermain Ramah Anak, Ada 13 Syarat Lho. [Internet]. Tersedia di: https://www.genpi.co/berita/9828/bang un-ruang-bermain-ramah-anak-ada-13 -syarat-lho diaskes pada 26 September 2019.

Image Bali Arsitek dan Kontraktor. 2019. Pengertian dan Cara Membuat Taman Air. [Internet]. Tersedia di: http://imagebali.net/detail-artikel/1238pengertian-dan-cara-membuat-tamanair.php diaskes pada 26 September 2019.

Kabupaten/Kota Layak Anak (KLA). 2017. Konsep Desain Tempat Bermain Anak. [Internet]. Tersedia di: http://www.kla.id/konsep-desain-tempa t-bermain-anak/ diaskes pada 26 September 2019.

Kementerian Pemberdayaan Perempuan dan Perlindungan Anak Republik Indonesia. 2019. KEMEN PPA :
Terapkan 13 Syarat RBRA, 4 Taman Ini Ramah Anak. [Internet]. Tersedia di:

https://www.kemenpppa.go.id/index.ph p/page/read/29/2354/kemen-pppa-tera pkan-13-syarat-rbra-4-taman-ini-ramah -anak diaskes pada 26 September 2019.

Nutriclub. Psikologi Perkembangan Anak Usia Dini yang Perlu Diketahui Mama. [Internet]. Tersedia di: https://www.nutriclub.co.id/article-balita /rutinitas-anak/rutinitas-anak-perilaku/p sikologi-perkembangan-anak-usia-diniyang-perlu-diketahui-mama diaskes pada 24 Juni 2020. 